\title{
Effect of ocean acidification on the benthic foraminifera Ammonia sp. is caused by a decrease in carbonate ion concentration
}

\author{
N. Keul ${ }^{1, *}$, G. Langer ${ }^{2}$, L. J. de Nooijer ${ }^{3}$, and J. Bijma ${ }^{1,4}$ \\ ${ }^{1}$ Alfred Wegener Institute, Am Handelshafen 12, Bremerhaven, 27570, Germany \\ ${ }^{2}$ Department of Earth Sciences, Cambridge University, Cambridge, CB2 3EQ, UK \\ ${ }^{3}$ Department of Marine Geology, Royal Netherlands Institute of Sea Research, Landsdiep 4, 1979 SZ, 't Horntje, the \\ Netherlands \\ ${ }^{4}$ Jacobs University, Earth and Space Sciences, Campus Ring 8, Bremen, 28759, Germany \\ *now at: Lamont-Doherty Earth Observatory, Geosciences, Columbia University, 61 Rd 9W Palisades, NY 10964, USA
}

Correspondence to: N. Keul (nkeul@1deo.columbia.edu)

Received: 27 September 2012 - Published in Biogeosciences Discuss.: 25 January 2013

Revised: 3 July 2013 - Accepted: 16 July 2013 - Published: 1 October 2013

\begin{abstract}
About $30 \%$ of the anthropogenically released $\mathrm{CO}_{2}$ is taken up by the oceans; such uptake causes surface ocean $\mathrm{pH}$ to decrease and is commonly referred to as ocean acidification (OA). Foraminifera are one of the most abundant groups of marine calcifiers, estimated to precipitate ca. $50 \%$ of biogenic calcium carbonate in the open oceans. We have compiled the state of the art literature on OA effects on foraminifera, because the majority of OA research on this group was published within the last three years. Disparate responses of this important group of marine calcifiers to OA were reported, highlighting the importance of a process-based understanding of OA effects on foraminifera. We cultured the benthic foraminifer Ammonia sp. under a range of carbonate chemistry manipulation treatments to identify the parameter of the carbonate system causing the observed effects. This parameter identification is the first step towards a process-based understanding. We argue that $\left[\mathrm{CO}_{3}^{2-}\right]$ is the parameter affecting foraminiferal sizenormalized weights (SNWs) and growth rates. Based on the presented data, we can confirm the strong potential of $\mathrm{Am}$ monia sp. foraminiferal SNW as a $\left[\mathrm{CO}_{3}^{2-}\right]$ proxy.
\end{abstract}

\section{Introduction}

During the last $800000 \mathrm{yr}$ atmospheric $\mathrm{CO}_{2}$ concentrations ranged from ca. 180 to $300 \mu$ atm (Petit et al., 1999; Siegenthaler et al., 2005). Since the start of industrialization, anthro- pogenic release of $\mathrm{CO}_{2}$ has caused atmospheric $\mathrm{CO}_{2}$ concentrations to increase steadily at a rapidly rising rate (currently ca. $0.5 \% \mathrm{yr}^{-1}$; Fabry et al., 2008). Approximately $30 \%$ of the carbon dioxide emissions are taken up by the oceans (Sabine et al., 2004). As a consequence of this, future surface ocean $\mathrm{pH}$ values are predicted to decrease 0.4 units (Caldeira and Wickett, 2005) by the end of this century. This decline is commonly referred to as ocean acidification (OA). Through the associated decrease in the calcium carbonate saturation state $(\Omega)$, biogenic calcification of ecologically important organisms such as corals, coccolithophorids and foraminifera is expected to be hampered. It is generally expected that coral calcification decreases under lower $\Omega_{\mathrm{a}}$ (aragonite saturation state) (Langdon and Atkinson, 2005). Responses of coccolithophorids with respect to OA are heterogeneous, and interand intra-species-specific differences have been documented (e.g., Langer et al., 2006, 2009; Langer and Bode, 2011). Foraminifera are one of the most abundant groups of calcifiers, estimated to precipitate ca. $50 \%$ of biogenic calcium carbonate in the open oceans (Schiebel, 2002). While the responses of coccolithophorids and corals have been extensively studied in the last $15 \mathrm{yr}$ and have been compiled in various studies (e.g., Doney et al., 2009), the majority of OA research on foraminifera was published in the last three years, and no overview of the state of the art exists. We have compiled the state of the art of OA effects on foraminifera. Disparate responses of this important group of marine calcifiers to $\mathrm{OA}$ were reported. In order to extract a coherent picture 
of OA effects on foraminifera from this wide spectrum of responses, it will ultimately be necessary to develop a processbased understanding of OA effects. The first step is the identification of the parameter of the carbonate system that causes the effects. Most carbonate chemistry perturbation experiments are characterized by a simultaneous change in several parameters of the carbonate system. This makes it impossible to separate, for example, carbonate ion effects from $\mathrm{pH}$ effects and to develop a process-based understanding of OA effects on foraminifera. We have conducted carbonate chemistry perturbation experiments with the benthic foraminifer Ammonia molecular type T6, further referred to as Ammonia sp. (Hayward et al., 2004) (please note that this species is also referred to as Ammonia tepida in other studies, e.g., de Nooijer et al., 2007; Dissard et al., 2010; Dueñas-Bohórquez et al., 2011; Raitzsch et al., 2010). We were following both the classical approach (i.e., co-varying $\left[\mathrm{CO}_{3}^{2-}\right]$ and $\mathrm{pH}$ ) as well as keeping $\mathrm{pH}$ constant while varying $\left[\mathrm{CO}_{3}^{2-}\right]$ to overcome this problem. The experimental setup used here allows us to distinguish between $\left[\mathrm{CO}_{3}^{2-}\right]$ and $\mathrm{pH}$ effects and potentially to identify a single parameter causing observed effects on Ammonia sp. (Langer and Bode, 2011).

\section{Material and methods}

\subsection{Sample collection and culturing}

Surface sediments were collected in the Wadden Sea near Dorum, Germany, between January and May 2011 and kept at $10^{\circ} \mathrm{C}$ as stock cultures after the removal of macrofauna. Living specimens (identified by their brightly colored yellow cytoplasm and pseudopodial activity) of Ammonia sp. were isolated from the stock cultures (de Nooijer et al., 2007; Raitzsch et al., 2010; Dueñas-Bohórquez et al., 2011) using a $230 \mu \mathrm{m}$ screen and transferred to well plates at $25^{\circ} \mathrm{C}$. Approximately $10 \%$ of the specimens reproduced asexually after about one week. Juveniles were kept for an additional 23 days until they added another $\sim 3$ chambers before they were transferred to culture experiments. Our culturing experience has shown that foraminifera have a high mortality when transferred into experimental conditions earlier than this ontogenetic stage.

\subsection{Seawater preparation}

Sterile-filtered $(0.2 \mu \mathrm{m}$ pore size $)$ North Sea seawater was used to prepare culture media for the experiments as described in Keul et al. (2013). The manipulated seawater was filled headspace-free into borosilicate flasks, sealed gas-tight with Teflon-lined caps and kept at $3{ }^{\circ} \mathrm{C}$ until used in the experiments. Two different carbonate chemistry perturbations were carried out, with four treatment levels each, leading to a total of eight treatments (Table 1):
1. TA manipulation: seawater with a range of $\mathrm{pHs}$ and $\left[\mathrm{CO}_{3}^{2-}\right]$ (4 in total), while total inorganic carbon concentration remained constant (TA denotes total alkalinity).

2. pH-stable manipulation: 4 treatments where DIC (dissolved inorganic carbon) and TA were manipulated in a way that $\mathrm{pH}$ was kept constant while the accompanying $p \mathrm{CO}_{2}$ values matched those of the TA manipulation.

\subsection{Experimental setup and culturing}

Long-term carbonate chemistry perturbation experiments require a special experimental setup, allowing stable carbonate system parameters over a long time period. We have constructed an experimental setup (Fig. 1) to allow for stable carbonate system parameters over long incubation periods and to ensure accessibility of the individuals (for feeding, regular water changes, etc). Asexually reproduced juveniles were placed into petri dishes containing the manipulated seawater and placed into one of four gas-tight boxes. A gas mixing system provided a steady gas flow $\left(60 \mathrm{~L} \mathrm{~h}^{-1}\right.$; see Hoppe et al., 2012 for a description of the gas flow controller) into the gas-tight boxes, at four different $p \mathrm{CO}_{2}$ concentrations (Table 1). Flow rate was constant and allowed a replacement of air inside the box every 10 minutes. Culturing took place in a temperature-controlled room at $26^{\circ} \mathrm{C}$ with a natural day/light cycle $(12 \mathrm{~h} / 12 \mathrm{~h})$. Supplied $p \mathrm{CO}_{2}$ of the gas mixtures was checked regularly. Borosilicate bottles containing the manipulated seawater were stored open in the boxes prior to water exchange to allow for pre-equilibration. Pre-equilibrated seawater was used to exchange the water in the petri dishes every 2-3 days. Foraminifera were fed photosynthetically inactive (heat sterilized) algae (Dunaliella salina) after the water was changed. To minimize potential effects of bacteria growing on the bottom of the dishes, petri dishes were exchanged every two weeks. The culturing period lasted for 59-96 days.

\subsection{Sample analysis}

\subsubsection{Carbonate chemistry}

DIC samples were filled headspace-free into acid-washed $13 \mathrm{~mL}$ borosilicate flasks and kept at $0^{\circ} \mathrm{C}$ until measurement (within days). DIC was measured in duplicates photometrically (Stoll et al., 2001) with a QuaAAtro autoanalyzer (Seal Analytical, Mequon, USA); average precision is $10 \mu \mathrm{mol} \mathrm{kg-sw}^{-1}$ based on repeated measurements of an in-house standard. Corrections for inaccuracies in the measurements were carried out by measuring Batch No. 54 of A. Dickson's CRMS (Certified Reference Material Seawater, Marine Physical Laboratory, Scripps Institution of Oceanography). A two-point NBS-calibrated glass electrode (Schott Instruments, Mainz, Germany) interfaced to a 
Table 1. Upper part: calculated and measured carbonate chemistry parameters of the eight treatments. "Nominal" $p \mathrm{CO}_{2}$ refers to the $p \mathrm{CO} 2$ supplied by the gas mixing system. A variety of input parameters (here $\mathrm{pH}$ and DIC) can be used to calculate the carbonate system and can be found in the supporting online material of Keul et al. (2013). Lower part: mean physiological parameters and 2 SE (standard errors).

\begin{tabular}{|c|c|c|c|c|c|c|c|c|}
\hline \multicolumn{9}{|c|}{ Treatments } \\
\hline & A1 & $\mathrm{A} 2$ & A3 & A4 & $\mathrm{B} 1$ & B2 & B3 & B4 \\
\hline & \multicolumn{8}{|c|}{ Seawater parameters } \\
\hline$p \mathrm{CO}_{2}(\mu \mathrm{atm})$ "nominal" & 180 & 380 & 950 & 1400 & 180 & 380 & 950 & 1400 \\
\hline$p \mathrm{CO}_{2}(\mu \mathrm{atm})$ & 217 & 479 & 850 & 1301 & 63 & 396 & 829 & 1252 \\
\hline $\mathrm{CO}_{3}^{2-}\left(\mu \mathrm{mol} \mathrm{kg}_{-} \mathrm{sw}^{-1}\right)$ & 401 & 224 & 136 & 88 & 21 & 152 & 405 & 563 \\
\hline $\mathrm{HCO}_{3}^{-}\left(\mu \mathrm{molkg}-\mathrm{sw}^{-1}\right)$ & 1798 & 1999 & 2073 & 2063 & 223 & 1499 & 3536 & 5131 \\
\hline $\operatorname{DIC}\left(\mu \mathrm{mol} \mathrm{kg-sw}{ }^{-1}\right)$ & 2205 & 2236 & 2232 & 2187 & 246 & 1662 & 3965 & 5729 \\
\hline $\mathrm{TA}\left(\mu \mathrm{molkg} \mathrm{sw}^{-1}\right)$ & 2747 & 2535 & 2400 & 2277 & 342 & 1884 & 4436 & 6343 \\
\hline pH (total scale) & 8.32 & 8.02 & 7.79 & 7.60 & 7.95 & 7.98 & 8.03 & 8.01 \\
\hline$\Omega_{\mathrm{c}}$ & 9.8 & 5.5 & 3.3 & 2.2 & 0.5 & 3.7 & 9.9 & 13.8 \\
\hline \multirow[t]{2}{*}[\mathrm{Ca}^{2+}]{$(\mathrm{mol} \mathrm{kg-sw}-1)$} & 0.009 & 0.009 & 0.009 & 0.009 & 0.009 & 0.009 & 0.009 & 0.008 \\
\hline & \multicolumn{8}{|c|}{ Physiological parameters } \\
\hline$n$ (number of specimens) & 15 & 14 & 37 & 39 & 36 & 21 & 19 & 24 \\
\hline Final weight $(\mu \mathrm{g})$ & 7.3 & 6.1 & 5.1 & 6.3 & 3.4 & 5.3 & 7.3 & 5.3 \\
\hline $2 \mathrm{SE}$ & 2.1 & 1.4 & 0.9 & 1.0 & 0.5 & 1.6 & 1.4 & 1.5 \\
\hline Final length $(\mu \mathrm{m})$ & 288 & 255 & 252 & 280 & 247 & 288 & 280 & 229 \\
\hline $2 \mathrm{SE}$ & 27 & 29 & 19 & 18 & 26 & 32 & 31 & 28 \\
\hline Growth rate $\left(10^{-2} \mu \mathrm{g} \mu \mathrm{m}^{-1}\right)$ & 11.20 & 7.28 & 7.55 & 9.71 & 5.99 & 9.33 & 12.75 & 9.01 \\
\hline $2 \mathrm{SE}$ & 3.17 & 2.34 & 1.17 & 1.43 & 0.89 & 2.72 & 2.53 & 2.56 \\
\hline $\operatorname{SNW}\left(10^{-2} \mu \mathrm{g} \mu \mathrm{m}^{-1}\right)$ & 2.41 & 2.19 & 1.89 & 2.14 & 1.33 & 1.70 & 2.48 & 2.29 \\
\hline $2 \mathrm{SE}$ & 0.48 & 0.37 & 0.23 & 0.24 & 0.14 & 0.33 & 0.38 & 0.67 \\
\hline
\end{tabular}

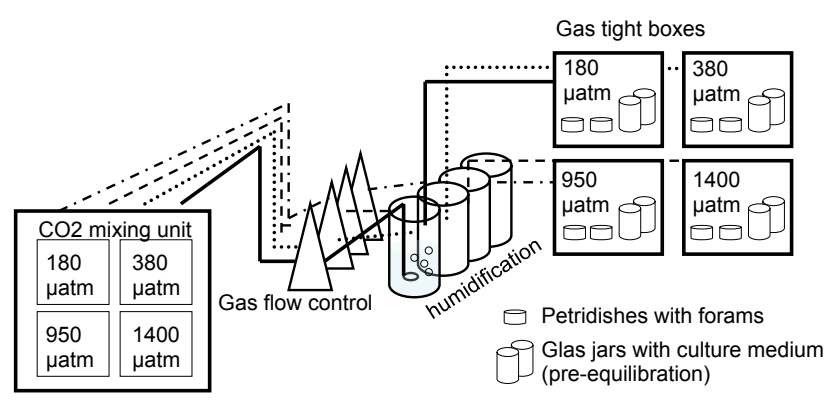

Fig. 1. Culturing setup: juvenile foraminifera were placed into petri dishes containing the manipulated seawater and placed into one of four gas-tight boxes, which were supplied with air of four different $p \mathrm{CO}_{2}$ concentrations (Table 1 ) by a gas mixing system. Borosilicate bottles containing the manipulated seawater were stored open in the boxes prior to water exchange in the culturing petri dishes to allow for pre-equilibration. Please note that $p \mathrm{CO}_{2}$ values given in the figure represent those supplied by the gas mixing system ("nominal" values in Table 1). The actual $p \mathrm{CO}_{2}$ value in the culturing petri dishes differs from these idealized values (see Table 1).

WTW $\mathrm{pH}$-meter was used to measure $\mathrm{pH}$ potentiometrically. Simultaneous measurement of a seawater buffer (Tris/Tris$\mathrm{HCl}$ prepared according to the recipe described in Dickson et al., 2007) allowed conversion of the $\mathrm{pH}$ values to the total scale. All pH values reported are on the total scale. Salinity and temperature were measured with a conductivity meter (WTW Multi 340i), interfaced with a TetraCon 325 sensor. pH and DIC (Hoppe et al., 2012) were used to calculate the carbonate system parameters $\left(\mathrm{CO}_{2} \mathrm{SYS}\right.$ program, adapted to Excel by Pierrot et al., 2006). The equilibrium constants for K1 and K2 of Mehrbach et al. (1973) as reformulated by Dickson and Millero (1987) were used.

\subsubsection{Growth rate and size-normalized weight}

Foraminiferal tests were soaked in concentrated $\mathrm{NaOCl}$ for ca. 20 min until all organic remains were removed (visual verification under the stereomicroscope), washed three times in deionized water and dried at room temperature over night. Sizes were measured under a stereomicroscope (Zeiss Stemi SV 11) using a Pyser bar scale, with a precision of $\pm 7.4 \mu \mathrm{m}$ under the used magnification of $66 \times$. Individual tests were weighed using an Ultra-Microbalance (Mettler Toledo UMX 2), with a precision of $0.1 \mu \mathrm{g}$.

Different terms are used in the literature to describe the rate of growth of foraminifera: growth rate, calcification rate and precipitation rate are among the commonly used terms, which, however, are not formally defined and thusly often confused with each other. We define growth rate as the amount of growth (here calculated as the increase in shell weight) of the whole specimen over time, whereas chamber formation rate is defined as the weight increase in calcium 
carbonate during chamber formation. While these two parameters can be measured (e.g., Glas et al., 2012; Anderson and Faber, 1984), the assessment of the rate of biogenic precipitation of calcium carbonate is complicated, since biogenic calcium carbonate precipitation is mediated by organic membranes, whose contribution (e.g., surface area) cannot be determined experimentally (see, e.g., Cuif et al., 2011 for an overview). Growth rates were calculated from the incubation period of individual shells and final shell weight and have the unit $\mu \mathrm{gday}^{-1}$ ind $^{-1}$ (ind =individual). (Please note that we assumed a constant initial weight since foraminifera were inserted to the experiment at the same development stage, allowing a comparison of growth rates. From the relationship between weight and size of specimen at the end of the experiment, we have calculated that the initial weight was at most ca. $10 \%$ of the final weight on average.) Foraminiferal shell weights increase with increasing shell diameter. The aim of size-normalized weight (SNW) is to remove this effect of shell diameter on the weight, making it possible to observe non-size-related variations in shell weight, for instance in shell thickness. Unfortunately the term size-normalized weight is used and defined incoherently in the literature; consequently a comparison of SNW between different studies might be hampered. We report SNW throughout this paper as the ratio of weight to diameter calculated for every specimen (unit $\mu \mathrm{g} \mu \mathrm{m}^{-1}$ ).

\subsection{Statistics}

All statistical tests were carried out using the statistics environment R (R Core Team, 2012). An ANOVA (analysis of variance) was performed to determine an effect of carbonate chemistry parameters on measured variables (diameter, weight, growth rate, SNW). Data were log-transformed to ensure normally distributed data (Shapiro test, $p>0.05$ ). Both Levene and Fligner tests confirmed homogenous variances of the dataset. The null hypothesis of the ANOVA (all group means are equal) was rejected if $p<0.05$. Tukey HSD (honestly significant difference) post hoc tests were performed to determine which means differed from each other. Linear regressions were performed with the built-in linear regression model. The homogeneity of regression slopes was assessed by means of a hoRS (homogeneity of regression slopes) model. The assumption of homogeneity of regression slopes was rejected if the respective $p$ value was significant $(p<0.05)$. Average values and 2 SE (standard error) are given throughout the text.

\section{Results}

\subsection{Carbonate chemistry}

Four $p \mathrm{CO}_{2}$ levels were maintained in the airtight boxes in which the petri dishes containing foraminifera were placed during the culturing period (180-1400 $\mu$ atm, nominal $p \mathrm{CO}_{2}$,
Table 1). Due to in- and outgassing, the respective $p \mathrm{CO}_{2}$ values of the culturing media were not exactly matching, in some treatments more than in others (especially the lowest $p \mathrm{CO}_{2}$ values). However, in order to analyze the effect of individual carbonate chemistry parameters on foraminiferal calcification, obtaining similar ranges of selected parameters is crucial, which is given in our experimental setup. The variation in $p \mathrm{CO}_{2}$ in the culturing seawater was in the same range as maintained in the boxes $(61-1301 \mu \mathrm{atm})$. $\mathrm{pH}$ was kept constant in the pH-stable manipulation (7.99 \pm 0.04$)$, while it varied in the TA manipulation between 7.60 at the highest and 8.32 at the lowest $p \mathrm{CO}_{2}$ level. Carbonate ion concentration decreased with increasing $p \mathrm{CO}_{2}$ in the TA manipulation (401-88 $\mu \mathrm{mol} \mathrm{kg-sw}{ }^{-1}$ ), whereas it increased with $p \mathrm{CO}_{2}$ in the $\mathrm{pH}$-stable manipulation $(21-563 \mu \mathrm{mol} \mathrm{kg}$ $\mathrm{sw}^{-1}$ ). DIC was kept quasi-constant in the TA manipulation $\left(2215 \pm 23 \mu \mathrm{mol} \mathrm{kg-sw}{ }^{-1}\right)$, whereas it increased with $p \mathrm{CO}_{2}$

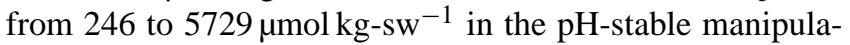
tion. TA increased from low to high $p \mathrm{CO}_{2}$ by almost a factor of 20 in the $\mathrm{pH}$-stable manipulation $(342-6343 \mu \mathrm{mol} \mathrm{kg}$ $\mathrm{sw}^{-1}$ ). The range in the TA manipulation with $470 \mu \mathrm{mol} \mathrm{kg-}$ $\mathrm{sw}^{-1}$ was comparably small. $\Omega_{\mathrm{c}}$ (calcite saturation state) was in all treatments $>1$ with a range of $\Omega_{\mathrm{c}}=2.2-13.8$, despite treatment $\mathrm{B} 1$, where the culturing media were undersaturated with respect to calcite $\left(\Omega_{\mathrm{c}}=0.5\right)$.

\subsection{Physiological responses}

Detailed growth characteristics such as calcification rates versus growth rates, carbonate chemistry factors influencing growth and the variability of all these amongst juvenile foraminifera have not been assessed yet for most foraminiferal species. In general, we observed a high variability in final shell diameter and weight among specimens (Table 1). Consequently, linear regression of individual growth characteristics (final diameter and weight, and factors such as SNW and growth rates derived thereof) versus carbonate chemistry parameters yields relatively low $R^{2}$ values (Table 2). If the observed high variability in growth characteristic was due to the effects of the carbonate chemistry manipulation, the control group A2 should display the lowest variability. Since this was not the case, we can assume that the observed variability has not been induced by our treatments and is a natural characteristic among the offspring of Ammonia sp. Table 2 contains the statistical output of a linear regression model performed on the average growth characteristics (length, weight, growth rate, SNW) versus carbonate chemistry parameters (as listed in Table 1).

\subsubsection{Length and weight}

Average final diameter varied between $247( \pm 26) \mu \mathrm{m}$ and $288( \pm 26) \mu \mathrm{m}$ (Table 1$)$. There was no statistically significant effect of any carbonate chemistry parameter on the final diameter $(p>0.05)$. Consequently, no linear regressions 
Table 2. Results of linear regression model between SNW and individual carbonate system parameters (based on averages of the eight treatments). Statistically significant regressions (at $p<0.05$ ) are displayed in bold.

\begin{tabular}{clllllll}
\hline Parameter & $\mathrm{CO}_{3}^{2-}$ & $\mathrm{pH}$ & $\mathrm{DIC}$ & $\mathrm{TA}$ & $\mathrm{HCO}_{3}^{-}$ & $\Omega_{\mathrm{c}}$ & $p \mathrm{CO}_{2}$ \\
\hline $\begin{array}{lllllll}\text { Length } \\
\quad\end{array}$ & 0.741 & 0.740 & 0.469 & 0.498 & 0.445 & 0.741 & 0.618 \\
$\quad R^{2}$ & 0.02 & 0.02 & 0.09 & 0.08 & 0.10 & 0.02 & 0.04 \\
$F$ & 0.12 & 0.12 & 0.60 & 0.52 & 0.67 & 0.12 & 0.28 \\
Weight & & & & & & & \\
$p$ & 0.171 & 0.428 & 0.311 & 0.281 & 0.341 & 0.171 & 0.566 \\
$R^{2}$ & 0.29 & 0.11 & 0.17 & 0.19 & 0.15 & 0.29 & 0.06 \\
$F$ & 2.42 & 0.72 & 1.22 & 1.40 & 1.07 & 2.42 & 0.36 \\
Growth Rate & & & & & & & \\
$p$ & 0.133 & 0.457 & 0.232 & 0.208 & 0.255 & 0.133 & 0.530 \\
$R^{2}$ & 0.33 & 0.10 & 0.23 & 0.25 & 0.21 & 0.33 & 0.07 \\
$F$ & 3.02 & 0.63 & 1.77 & 1.99 & 1.58 & 3.02 & 0.44 \\
SNW & & & & & & & \\
$p$ & $\mathbf{0 . 0 2 7}$ & 0.463 & $\mathbf{0 . 0 4 7}$ & $\mathbf{0 . 0 3 9}$ & 0.060 & $\mathbf{0 . 0 2 7}$ & 0.247 \\
$R^{2}$ & 0.59 & 0.09 & 0.51 & 0.54 & 0.48 & 0.59 & 0.22 \\
$F$ & 8.49 & 0.61 & 6.24 & 6.93 & 6.61 & 8.50 & 0.25 \\
\hline
\end{tabular}

were performed. The lowest final weight was measured on shells grown in treatment B1 (average: $3.4 \pm 0.5 \mu \mathrm{g}$ ), which was undersaturated with respect to calcite. Based on the results of the ANOVA, all carbonate chemistry parameters despite $\mathrm{pH}$ could have had a positive effect on final shell weight $(p<0.05)$. The linear regression model reveals that the carbonate ion concentration can explain the highest amount of variability (29\%) in averaged shell weights and $p \mathrm{CO}_{2}$ the lowest $(6 \%)$.

\subsubsection{Growth rate}

Growth rates are given as $\mu \mathrm{g} \mathrm{d}^{-1}$ ind $^{-1}$ (Table 1). Average growth rates displayed the same variation in the TA manipulation (7.55-11.20 $\mathrm{g} \mathrm{d}^{-1}$ ind $^{-1}$ ) when compared to the $\mathrm{pH}$ stable manipulation (5.99-12.75 $\mu \mathrm{g} \mathrm{d}^{-1}$ ind $\left.^{-1}\right)$, with a range in variability between ca. 15 and $30 \%$ (2 SE) in both manipulations. Growth rates display a positive correlation with all carbonate system parameters except $\mathrm{pH}$ and $\mathrm{pCO}_{2}(p<$ $0.05)$.

\subsubsection{Size-normalized weight}

Average SNW varied between $2.48( \pm 0.38)$ and $1.33( \pm 0.14)$ $10^{-2} \mu \mathrm{g} \mu \mathrm{m}^{-1}$ in the different treatments, whereas measured SNW on single specimens was up to $4 \times 10^{-2} \mu \mathrm{g} \mu \mathrm{m}^{-1}$. Linear regression of SNW and carbonate chemistry parameters on all eight treatments together reveals a positive correlation $(p<0.05)$ between SNW and carbonate ion concentration, DIC, TA and $\Omega_{\mathrm{c}}$ (see Table 2 for statistical output). However, when separating the two manipulations graphically (Fig. 2), it becomes obvious that the general trends of the two regression slopes (positive/negative) coincide only when plotted against carbonate ion concentration (Fig. 2c) and TA
(Fig. 2e). A tool to assess the difference in regression slopes is hoRS analysis, which checks for homogeneity of regression slopes. The results of this analysis reveal that regression slopes of the two manipulations are homogenous $(p>0.05)$ in the regressions of carbonate ion concentration, DIC and TA, only (represented by a star in Fig. 2).

\section{Discussion}

\subsection{Overview of foraminiferal studies with a focus on carbonate chemistry}

Over the recent years, a number of studies (Table 3) have assessed the effects of OA on foraminifera. Approaches were ranging from culturing under different $p \mathrm{CO}_{2}$ treatments, looking at the geological past either through sediment core tops or whole cores, to assessing whole communities at naturally occurring $p \mathrm{CO}_{2}$ gradients. Studied response parameters were shell weight, SNW, size, growth/calcification rates and shell thickness and changes in communities (diversity, abundance). A multitude of responses have been documented that range from no effect of $p \mathrm{CO}_{2}$, an increase/decrease (mostly) with increasing $p \mathrm{CO}_{2}$ to more complex responses where an initial increase up to a certain intermediate $p \mathrm{CO}_{2}$ level was followed by a decrease. These differences are most likely not only attributed to the species studied but also to the methods used. Deconvolving method effects from speciesspecific effects can be achieved. Subjecting different species to the same method allows detection of species-specific effects, whereas the method effects can be assessed by subjecting the same species to different methods. Deconvolving species-specific differences was, for instance, possible in the study of Fujita et al. (2011), where the responses to 

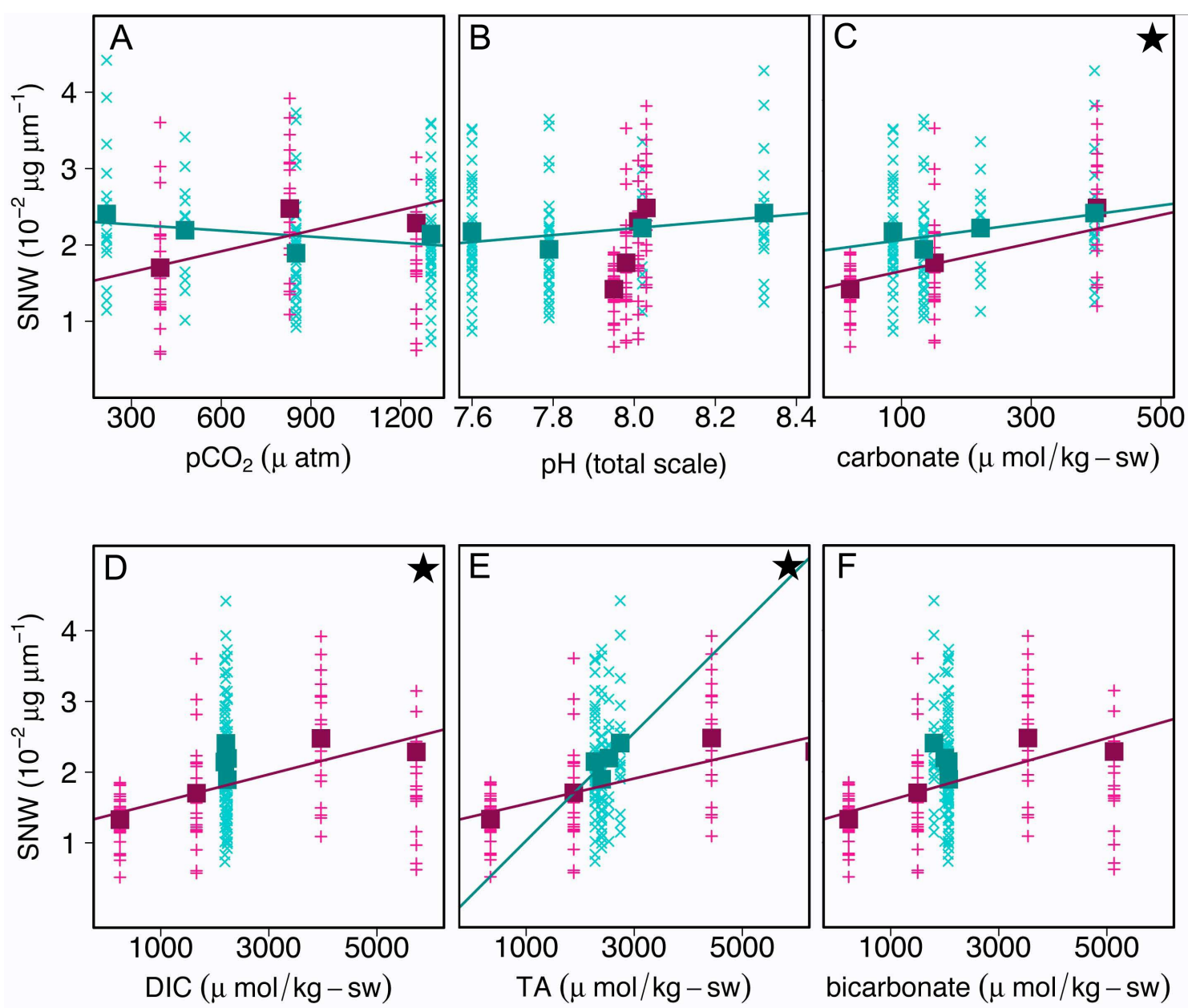

Fig. 2. SNW versus carbonate system parameters. Cyan $x$ and pink + represent SNW of individual shells in the TA manipulation and the $\mathrm{pH}$-stable manipulation, respectively. Closed squares in cyan and pink represent average SNW in the TA manipulation and the pH-stable manipulation, respectively. Cyan and pink lines represent linear regression lines for SNW versus the respective carbonate system parameter (TA- and $\mathrm{pH}$-stable manipulation). Stars in the upper right corner represent a statistically significant (hoRS model, at $p<0.05$ ) homogeneity of regression slopes. Due to the relatively small ranges in $x$ axis, variations in some correlations (e.g., TA manipulation in D), the significance of regression slopes and thus the hoRS model is confined. Regression slopes have been omitted in these cases.

elevated $p \mathrm{CO}_{2}$ of three foraminiferal species were studied. The difference in the response patterns has been speculated by these authors to be attributed to the different calcification pathways of hyaline and porcellanous species (e.g. Ter Kuile et al., 1989). Calcification was elevated at intermediate levels of $p \mathrm{CO}_{2}$ in the case of the hyaline species (Baculogypsina sphaerulata, Calcarina gaudichaudii), whereas a decrease in calcification accompanied increasing $p \mathrm{CO}_{2}$ values in $\mathrm{Am}$ phisorus hemprichii, a porcellaneous species. Four studies investigated the effect of elevated $p \mathrm{CO}_{2}$ on Marginopora, a larger benthic foraminifera. A comparison of these studies could help to infer differences in responses attributed to different methods used. Vogel and Uthicke (2012) observed an increase in calcification rates with $p \mathrm{CO}_{2}$ for M. vertebralis, whereas in both the studies of Sinutok et al. (2011) and Kuroyanagi et al. (2009) the opposite effect was detected (the latter study investigated a closely related foraminifera, M. kudakajimensis). This difference could be attributed to the employed manipulation methods (Kuroyanagi et al., 2009: TA manipulation and Vogel and Uthicke, 2012: DIC manipulation, manipulation of DIC by aeration with a certain $p \mathrm{CO}_{2}$ ) or the chosen experimental setup (static/flow-through). The first option seems unrealistic in the light of a study of Hoppe et al. (2011), where the effect of elevated $p \mathrm{CO}_{2}$ in TA versus DIC manipulations was found to be the same for the coccolithophorid Emiliania huxleyi. Additionally, opposing responses were also detected by Vogel and Uthicke (2012) and Sinutok et al. (2011), who both used DIC manipulations. Comparing laboratory to field studies can also shed light on differences in response patterns. For instance Uthicke and Fabricius (2012) found that M. vertebralis was not present in the field at $p \mathrm{CO}_{2}$ values of $700 \mu \mathrm{atm}$, as opposed to high 
abundances at control sites with present-day $p \mathrm{CO}_{2}$. This might indicate that the latter species suffers from increased $p \mathrm{CO}_{2}$ and that the increased calcification rate with increasing $p \mathrm{CO}_{2}$ reported by Vogel and Uthicke (2012) is a laboratory artifact that does not apply to the field. As a caveat it must be added here that it is also possible that an environmental parameter other than, but correlating with, $p \mathrm{CO}_{2}$ caused the absence of $M$. vertebralis at $700 \mu$ atm $p \mathrm{CO}_{2}$. Another factor that could result in different calcification responses under changing carbonate chemistry in different species is the presence or absence of symbionts. By photosynthesis and respiration, symbionts may alter the carbonate system in the direct surrounding of the foraminifer and thus modify ambient values for $\mathrm{pH}$, TA, etc (e.g. Rink et al., 1998).

Comparing these studies on a methodological level is beyond the scope of this paper and might better be done in a separate study. The variety in responses shows, however, that there is no uniform response of foraminifera to OA. This makes it difficult to predict the overall response of foraminifera to ongoing OA and the subsequent impacts on biogeochemical cycling and ecology. To facilitate estimations on future foraminiferal functioning despite interspecies variability in calcification responses, an understanding of the physiological basis of calcification (and variability between species) is necessary (see also Rost et al., 2008). At the same time, such a biomineralization model may also explain the apparent variability in calcification responses observed so far (Table 3). In addition, a process-based characterization of foraminiferal calcification will also help to understand the impact of different parameters of the carbonate system on elemental incorporation and stable isotope fractionation, thereby improving their paleoceanographic potential. On long timescales, changes in the individual parameters of the C-system (e.g., alkalinity and $\mathrm{pH}$ ) may not have been tightly coupled. Together, these two objectives make it necessary to study impacts of the different carbonate system components individually. Therefore, we cultured specimens of the benthic foraminifer Ammonia sp. under two carbonate chemistry manipulations, allowing the quantification of impacts of carbonate ion concentration as well as $\mathrm{pH}$.

\subsection{Growth rate}

The comparison of foraminiferal growth rates is complicated by the fact that, as a rule, juvenile specimens grow faster than adult specimens. Hence comparing the growth rate of a juvenile to the one of an adult will result in a bias (i.e., a relative over-estimation of the juvenile growth rate). However, this bias cannot be detected in our data, because size and growth rates are positively correlated (Fig. 3). This reflects the fact that our specimens were not fully grown when harvested. It will be helpful to clarify the terminology used in the context of foraminiferal growth. In general, rates are often reported in units of mass of $\mathrm{CaCO}_{3}$ deposited/time. This unit might

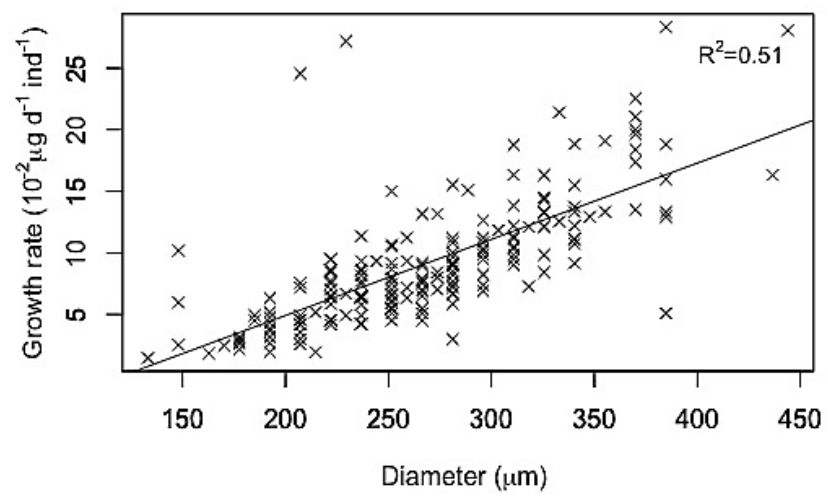

Fig. 3. Growth rates $\left(10^{-2} \mu \mathrm{g} \mathrm{d}^{-1}\right.$ ind $\left.^{-1}\right)$ of all treatments versus diameter $(\mu \mathrm{m})$.

be applied to an individual over a period of several weeks, but might also be applied to a single chamber-formation event. These two numbers represent distinct parameters and must not be confused, because there are considerable time spans separating two chamber formation events (Hemleben et al., 1987). To illustrate this, we compare our overall average growth rate (which represents the sum of many chamber formation events including the time spans separating them) with the chamber-formation rate determined by Glas et al. (2012). Please note that the latter authors used the term calcification rate, again highlighting the need for clarity in matters of foraminiferal rates (growth, calcification, chamber formation). Our overall average of growth rates is $0.09 \mu \mathrm{g} \mathrm{d}^{-1}$ ind $^{-1}\left(=0.00375 \mu \mathrm{g} \mathrm{h}^{-1}\right.$ ind $\left.^{-1}\right)$, which is lower than their measured calcification rate $\left(0.028 \mu \mathrm{g} \mathrm{h}^{-1}\right.$, Glas et al., 2012). Hence, the inclusion of non-chamber-formation times reduces the rate by one order of magnitude. We suggest using terminology as specific as possible (e.g. chamber formation rate instead of calcification rate) and, most importantly, reporting exactly how rates in terms of mass of $\mathrm{CaCO}_{3}$ deposited/time were determined.

\subsection{Ecophysiological responses to carbonate chemistry}

We used two different methods to manipulate the seawater carbonate chemistry: a TA manipulation (treatments A1-A4, Table 1) and a pH-stable manipulation (treatments B1-B4, Table 1). Since the carbonate system parameters co-vary differently in the two experimental approaches, it is possible, by exclusion, to reject certain parameters of the carbonate system as causes for the observed changes in SNW (Table 1). The general idea behind this is that the responsible parameter should cause the same trends in SNW in both manipulations (e.g., characterized by similar regression slopes).

\subsubsection{Shell thickness (as size-normalized weight)}

When pooling all eight treatments, average SNW is positively correlated with $p \mathrm{CO}_{2}\left(R^{2}=0.22\right)$, however, not 
Table 3. Overview of foraminiferal response patterns to changes in carbonate chemistry. Responses are represented by simple trend plots. $\mathrm{pH}, p \mathrm{CO}_{2}$ and other carbonate system parameters covary in TA and DIC manipulation studies. This renders it possible to read off the respective $p \mathrm{CO}_{2}$ response, where not directly given, to enhance comparability. Analyzed parameters vary by study: shell weight, SNW (size-normalized weight), size, growth/calcification rates (see Sect. 4.2) and shell thickness. Responses are represented by simple trend plots. Those studies assessing the affects of OA on foraminiferal communities (diversity, abundance) have not been depicted by these trend plots (NA - not applicable). The studies were categorized as follows: $\mathrm{G}=$ geological record $\left(\mathrm{G}_{\mathrm{CT}}=\right.$ core tops, $\mathrm{G}_{\mathrm{C}}=\mathrm{down}$ core $), \mathrm{O}=\mathrm{open}$ ocean $\left(\mathrm{O}_{\mathrm{ST}}=\right.$ sediment trap, $\mathrm{OPT}_{\mathrm{PT}}=$ plankton tow $), \mathrm{C}=$ culture experiments $\left(\mathrm{C}_{\mathrm{rep}}=\right.$ asexually reproduced individuals, $\mathrm{C}_{\mathrm{ad} / \mathrm{juv}}=\mathrm{adult} / \mathrm{juvenile}$ individuals collected from their natural habitat), and $\mathrm{O}=$ other type.

\begin{tabular}{lllll}
\hline Study & Species & Type & Methods & $\begin{array}{l}\text { Response } \\
\text { to } p \mathrm{CO}_{2}\end{array}$ \\
\hline $\begin{array}{l}\text { Allison et al. } \\
(2010)\end{array}$ & E. williamsoni & $\mathrm{C}_{\mathrm{ad}}$ & $\begin{array}{l}\mathrm{TA} \text { manipulation } \\
3 \mathrm{pH}(7.7-8.3), 8 \text { weeks }\end{array}$ \\
\hline $\begin{array}{l}\text { Barker and } \\
\text { Edlerfield } \\
(2002)\end{array}$ & G. bulloides & $\mathrm{G}_{\mathrm{C}}$ & $\begin{array}{l}\text { Comparison of } \mathrm{G}_{\mathrm{C}} \\
\text { SNW and carbonate } \\
\text { system }\end{array}$ \\
\hline $\begin{array}{l}\text { Beer et al. } \\
(2010)\end{array}$ & G. bulloides & OPT & $\begin{array}{l}\text { Comparison of OPT SNW } \\
\text { and carbonate system }\end{array}$ \\
\cline { 2 - 6 } & G. ruber & &
\end{tabular}

Response parameter

Chambers formed at low $\mathrm{pH}$ significantly thinner than at high $\mathrm{pH}$

- Glacial: highest shell weights

- shell weights seem to be carbonate system-influenced

Strong interspecies variations: different response of $\mathrm{SNW}$ to $p \mathrm{CO}_{2}$

Difference in relative abundances (G. bull. low carb/high $p \mathrm{CO}_{2} / G$. ruber high carb/low $p \mathrm{CO}_{2}$ )

\begin{tabular}{llll}
\hline $\begin{array}{l}\text { Bijma et al. } \\
(1999,2002)\end{array}$ & $\begin{array}{l}\text { O. universa } \\
\text { G. sacculifer }\end{array}$ & $\mathrm{C}_{\mathrm{juv}}$ & $\begin{array}{l}\text { TA, DIC and } \mathrm{pH} \text {-stable } \\
\text { manipulation }(O \text {. uni- } \\
\text { versa }) \text {, G. sacculifer } \text { only } \\
\text { TA manipulation }\end{array}$
\end{tabular}

\begin{tabular}{|c|c|c|c|c|c|}
\hline $\begin{array}{l}\text { de Moel et al. } \\
(2009)\end{array}$ & G. ruber & $\begin{array}{l}\mathrm{G}_{\mathrm{CT}} \\
\mathrm{G}_{\mathrm{C}}\end{array}$ & Comparison of weights & & $\begin{array}{l}\text { - Weight: lighter foraminifera in } \mathrm{G}_{\mathrm{CT}} \text { than } \\
\text { in } \mathrm{G}_{\mathrm{C}} \\
\text { - Age: light-shelled specimens are } \\
\text { younger }\end{array}$ \\
\hline $\begin{array}{l}\text { Dias et al. } \\
(2010)\end{array}$ & $\begin{array}{l}\text { Various perforate \& } \\
\text { imperforate species }\end{array}$ & $\mathrm{G}_{\mathrm{CT}}$ & $\begin{array}{l}\text { Assemblage study at } \\
\text { different natural } \mathrm{pH} \\
\text { gradients }(8.1-6.6)\end{array}$ & NA & $\begin{array}{l}\text { - Reduction in diversity and abundance } \\
\text { - Shift from } 24 \text { to } 4 \text { sp. (all agglutinated) } \\
\text { with decreasing pH }\end{array}$ \\
\hline $\begin{array}{l}\text { Dissard et al. } \\
(2010)\end{array}$ & A. tepida & $\mathrm{C}_{\mathrm{ad}}$ & $\begin{array}{l}\text { DIC manipulation: } \\
230+1990 \mu \text { atm } p \mathrm{CO}_{2}\end{array}$ & & $\begin{array}{l}\text { Higher shell-weights in low } p \mathrm{CO}_{2} \\
\text { treatments }\end{array}$ \\
\hline \multirow[t]{2}{*}{$\begin{array}{l}\text { Fujita et al. } \\
(2011)\end{array}$} & $\begin{array}{l}\text { B. sphaerulata } \\
\text { C. gaudichaudii }\end{array}$ & \multirow[t]{2}{*}{$\mathrm{C}_{\mathrm{rep}}$} & \multirow{2}{*}{$\begin{array}{l}\text { DIC manipulation, } \\
12 \text { weeks, } 5 \mathrm{pCO}_{2} \text { levels } \\
(260-970 \mu \mathrm{atm})\end{array}$} & & $\begin{array}{l}\text { Weight increases at intermediate } \\
p \mathrm{CO}_{2} \text { levels, then decreases }\end{array}$ \\
\hline & A. hemprichii & & & & $\begin{array}{l}\text { Weights decreased under higher } p \mathrm{CO}_{2} \\
\text { levels }\end{array}$ \\
\hline $\begin{array}{l}\text { Glas et al. } \\
(2012)\end{array}$ & $\begin{array}{l}4 \text { photosymbiotic } \\
\text { (M. vertebralis, } \\
\text { H. depressa, A. ra- } \\
\text { diata, Peneroplis } \\
\text { sp.), } 2 \text { non-symbio- } \\
\text { tic species (Quin- } \\
\text { queloculina sp., } \\
\text { Miliola } \text { sp.) }\end{array}$ & $\mathrm{O}$ & $\begin{array}{l}\text { Short-term incubation } \\
\text { under } 3 \mathrm{pCO}_{2} \text { levels } \\
\text { (ca. } 430-2150 \mu \mathrm{atm}) \\
\text { microelectrode } \\
\text { measurements }\end{array}$ & NA & $\begin{array}{l}\text { Photosynthetic increase of surface } \mathrm{pH} \\
\text { insufficient to compensate for seawater } \\
\mathrm{pH} \text { decreases. Photosynthesis only partly } \\
\text { protects symbiont bearing foraminifera } \\
\text { against OA }\end{array}$ \\
\hline \multirow[t]{2}{*}{$\begin{array}{l}\text { Gonzalez-Mora } \\
\text { et al. (2009) }\end{array}$} & $\begin{array}{l}\text { G. bulloides \& } \\
\text { G. ruber }\end{array}$ & \multirow[t]{2}{*}{$\mathrm{G}_{\mathrm{C}}$} & \multirow{2}{*}{$\begin{array}{l}\text { Comparison of } \mathrm{G}_{\mathrm{C}} \\
\text { weights and Vostok } \\
p \mathrm{CO}_{2} / \mathrm{Mg} / \mathrm{Ca}-\mathrm{Temp} \text {. }\end{array}$} & & $\begin{array}{l}\text { Link between down-core shell weight } \\
\text { decrease and high } p \mathrm{CO}_{2} \text { values }\end{array}$ \\
\hline & N. pachyderma & & & & Weights more influenced by temperature \\
\hline
\end{tabular}


Table 3. Continued.

\begin{tabular}{|c|c|c|c|c|c|}
\hline Study & Species & Type & Methods & $\begin{array}{l}\text { Response } \\
\text { to } \mathrm{pCO}_{2}\end{array}$ & Response parameter \\
\hline $\begin{array}{l}\text { Haynert et al. } \\
(2011)\end{array}$ & A. aomoriensis & $\mathrm{C}_{\mathrm{ad}}$ & $\begin{array}{l}\text { DIC manipulation } \\
6 \text { weeks, } 5 \mathrm{pCO}_{2} \text { levels } \\
(620-3130 \mu \mathrm{atm})\end{array}$ & & $\begin{array}{l}\text { - Reduced calcification at elevated } p \mathrm{CO}_{2} \\
\text { - Decalcification started at } 930 \mathrm{~atm}\end{array}$ \\
\hline $\begin{array}{l}\text { Haynert et al. } \\
(2012)\end{array}$ & $\begin{array}{l}\text { Dominance: } \\
\text { A. aomoriensis } \\
\text { E. incertum } \\
\text { A. cassis }\end{array}$ & $\mathrm{G}_{\mathrm{CT}}$ & $\begin{array}{l}\text { Assemblage study at } \\
\text { different natural } p \mathrm{CO}_{2} \\
\text { fluctuation } \\
(1200-3300 \mu \mathrm{atm})\end{array}$ & NA & $\begin{array}{l}\text { - Seasonal community shifts } \\
\text { - No dynamic response between popula- } \\
\text { tion density/diversity and pore water } \\
p \mathrm{CO}_{2}\end{array}$ \\
\hline \multirow[t]{3}{*}{$\begin{array}{l}\text { Hikami et al. } \\
(2011)\end{array}$} & C. gaudichaudii & $\mathrm{C}_{\mathrm{juv}}$ & $\begin{array}{l}6 \text { weeks, DIC-manipu- } \\
\text { lation, } 4 p \mathrm{CO}_{2} \text { treat- } \\
\text { ments }(250-910 \mu \mathrm{atm})\end{array}$ & & Net calcification increased with $p \mathrm{CO}_{2}$ \\
\hline & A. kudakajimensis & & & & Reduced net calcification \\
\hline & A. hemprichii & & $\begin{array}{l}\text { Constant carbonate } \\
\text { ion concentration }\end{array}$ & NA & $\begin{array}{l}\text { Constant calcification under constant } \\
\text { carbonate ion concentration }\end{array}$ \\
\hline $\begin{array}{l}\text { Kuroyanagi et } \\
\text { al. (2009) }\end{array}$ & M. kudakajimensis & $\mathrm{C}_{\mathrm{rep}}$ & $\begin{array}{l}\text { TA manipulation, } \\
10 \text { weeks, } 4 \mathrm{pH} \text { levels } \\
(7.7-8.3)\end{array}$ & & $\begin{array}{l}\text { - Weight, shell size, growth rates decrease } \\
\text { with decreasing pH } \\
\text { - No statistical difference in responses at } \\
\text { pH } 7.9+8.2\end{array}$ \\
\hline $\begin{array}{l}\text { Lombard et al. } \\
\text { (2010) }\end{array}$ & $\begin{array}{l}\text { G. sacculifer } \\
\text { O. universa }\end{array}$ & $\mathrm{C}_{\mathrm{juv}}$ & $\begin{array}{l}\text { TA manipulation, } \\
\text { additional light treat- } \\
\text { ments, } 4-7 \mathrm{~d} \text { incubation }\end{array}$ & & $\begin{array}{l}\text { Reduced final shell weight and calcifica- } \\
\text { tion rate under low carbonate ion concen- } \\
\text { tration in both species }\end{array}$ \\
\hline $\begin{array}{l}\text { Manno et al. } \\
(2012)\end{array}$ & N. pachyderma & $\begin{array}{l}\mathrm{C}_{\mathrm{ad}} \\
\mathrm{C}_{\mathrm{juv}}\end{array}$ & $\begin{array}{l}2 \mathrm{pH} \text { and } 2 \text { temp. treat- } \\
\text { ments, 6-day incuba- } \\
\text { tion, juvenile + adults }\end{array}$ & & $\begin{array}{l}\text { Decrease in size, weight and thus calc. } \\
\text { rate in low } \mathrm{pH} \text { treatment }(7.8)\end{array}$ \\
\hline $\begin{array}{l}\text { McIntyre- } \\
\text { Wressnig et } \\
\text { al. (2013) }\end{array}$ & A. gibbosa & $\mathrm{C}_{\mathrm{ad}}$ & $\begin{array}{l}6 \text { weeks, DIC manipu- } \\
\text { lation }\left(p \mathrm{CO}_{2} \text { : }\right. \\
410-2000 \mu \mathrm{atm})\end{array}$ & & $\begin{array}{l}\text { No carbonate system effect on survival, } \\
\text { growth }\end{array}$ \\
\hline \multirow[t]{2}{*}{$\begin{array}{l}\text { Moy et al. } \\
(2009)\end{array}$} & G. bulloides & $\begin{array}{l}\mathrm{G}_{\mathrm{CT}} \\
\mathrm{O}_{\mathrm{ST}} \\
\mathrm{G}_{\mathrm{C}}\end{array}$ & $\begin{array}{l}\text { Comparison of } \mathrm{G}_{\mathrm{CT}} \\
\text { and } \mathrm{O}_{\mathrm{ST}}\end{array}$ & & $\begin{array}{l}\text { - } 30-35 \% \text { decrease in shell weights } \\
\text { between } \mathrm{O}_{\mathrm{ST}} \text { and } \mathrm{G}_{\mathrm{CT}}\end{array}$ \\
\hline & & & $\begin{array}{l}\text { Comparison of } \mathrm{G}_{\mathrm{C}} \\
\text { weights and Vostok } \\
p \mathrm{CO}_{2}\end{array}$ & & $\begin{array}{l}\text { - Link between down-core shell weight } \\
\text { decrease and high } p \mathrm{CO}_{2} \text { values for last } \\
50000 \mathrm{yr}\end{array}$ \\
\hline $\begin{array}{l}\text { Naik et al. } \\
(2010)\end{array}$ & G. sacculifer & $\mathrm{G}_{\mathrm{C}}$ & $\begin{array}{l}\text { Comparison of } \mathrm{G}_{\mathrm{C}} \\
\text { weights and Vostok } \\
p \mathrm{CO}_{2} / \mathrm{Mg} / \mathrm{Ca}-\mathrm{Temp}\end{array}$ & & $\begin{array}{l}\text { Link between down-core shell weight } \\
\text { decrease and high } p \mathrm{CO}_{2} \text { values }\end{array}$ \\
\hline $\begin{array}{l}\text { Reymond et al. } \\
\text { (2013) }\end{array}$ & M. rossi & $\mathrm{C}_{\mathrm{ad}}$ & $\begin{array}{l}\text { DIC manipulation, } \\
5 \text { weeks }(\mathrm{pH} 7.6-8.1)\end{array}$ & & $\begin{array}{l}\text { - Reduced growth under lower } \mathrm{pH} \\
\text { - interactive impact of eutrophication }\end{array}$ \\
\hline $\begin{array}{l}\text { Russell et al. } \\
(2004)\end{array}$ & O. universa & $\mathrm{C}_{\mathrm{juv}}$ & $\begin{array}{l}\text { TA manipulation } \\
\left(\left[\mathrm{CO}_{3}^{2-}\right]=110-\right. \\
\left.470 \mu \mathrm{mol} \mathrm{kg-sw}^{-1}\right)\end{array}$ & & $\begin{array}{l}\text { Shell weights increase with carbonate ion } \\
\text { concentration }\end{array}$ \\
\hline $\begin{array}{l}\text { Sinutok et al. } \\
\text { (2011) }\end{array}$ & M. vertebralis & $\mathrm{C}_{\mathrm{ad}}$ & $\begin{array}{l}\text { DIC manipulation, } \\
4 \text { weeks (pH 7.4-8.1) }\end{array}$ & & $\begin{array}{l}\text { Reduced calcification under elevated } \\
p \mathrm{CO}_{2}\end{array}$ \\
\hline
\end{tabular}


Table 3. Continued.

\begin{tabular}{|c|c|c|c|c|c|}
\hline Study & Species & Type & Methods & $\begin{array}{l}\text { Response } \\
\text { to } p \mathrm{CO}_{2}\end{array}$ & Response parameter \\
\hline \multirow{2}{*}{$\begin{array}{l}\text { Uthicke and } \\
\text { Fabricius } \\
\text { (2012) }\end{array}$} & M. vertebralis & $\mathrm{C}_{\mathrm{ad}}$ & DIC manipulation & & Reduced calcification at high $p \mathrm{CO}_{2}$ \\
\hline & & $\mathrm{O}$ & $\begin{array}{l}\text { Natural } p \mathrm{CO}_{2} \\
\text { gradients }\end{array}$ & NA & Absent in field at $p \mathrm{CO}_{2}$ of $700 \mu \mathrm{atm}$ \\
\hline \multirow[t]{2}{*}{$\begin{array}{l}\text { Vogel and } \\
\text { Uthicke (2012) }\end{array}$} & $\begin{array}{l}\text { A. radiata } \\
\text { H. depressa }\end{array}$ & $\mathrm{C}_{\mathrm{ad}}$ & $\begin{array}{l}6 \text { weeks, DIC-manipu- } \\
\text { lation, } 4 \mathrm{pCO}_{2} \text { treat- }\end{array}$ & & Growth rates not affected by $p \mathrm{CO}_{2}$ \\
\hline & M. vertebralis & & ments (470-1925 $\mu \mathrm{atm})$ & & $\begin{array}{l}\text { Significantly increased calcification rates } \\
\text { at high } p \mathrm{CO}_{2}\end{array}$ \\
\hline
\end{tabular}

at a statistically significant level $(p>0.05)$. Furthermore, hoRS analysis reveals that regression slopes are heterogeneous (at $p<0.05$ ) in the two manipulations: in the $\mathrm{pH}$-stable manipulation, average SNW displays a positive correlation with $p \mathrm{CO}_{2}\left(R^{2}=0.77\right)$, whereas the correlation of average SNW and $p \mathrm{CO}_{2}$ is negative $\left(R^{2}=0.38\right)$ in the TA manipulation (Fig. 2a). Thus, $p \mathrm{CO}_{2}$ cannot be the parameter of the carbonate system causing a change in SNW. While average SNW is positively correlated to bicarbonate ion concentration $\left(R^{2}=0.81\right)$ in the $\mathrm{pH}$-stable manipulation, the correlation is negative $\left(R^{2}=0.76\right)$ in the TA manipulation and hoRS analysis reveals that regression slopes are heterogeneous at $p=0.05$. Please note that SNW-bicarbonate correlation in the TA manipulation is based on a much smaller range of bicarbonate concentrations than in the case of the $\mathrm{pH}$-stable manipulation. This renders the correlation less reliable (despite the relatively high $R^{2}$ ). We point out, however, that even assuming that the cyan trend line in Fig. 2f was vertical, it has to be concluded that bicarbonate cannot be the parameter of the carbonate system causing SNW to vary. The reason is that the range in SNW in the TA manipulation is, by comparison with the $\mathrm{pH}$-stable manipulation, too large with respect to the scatter in bicarbonate concentration. SNW displays overall a positive correlation with $\mathrm{pH}$ (Fig. 2b). However, this has to be interpreted as a coincidence, because the slope of the correlation in the $\mathrm{pH}$-stable manipulation is about a factor of 30 steeper than in the TA manipulation: if the correlation were causal, then the two slopes should be similar. This is also supported by the hoRS model, which indicates that the two slopes are not homogenous $(p<0.05)$. The large scatter in SNW in the pH-stable manipulation cannot be caused by the insignificant differences in $\mathrm{pH}$ and must therefore be caused by another carbonate system parameter, excluding $\mathrm{pH}$ as the SNW-influencing parameter $(p>0.05)$. A similar reasoning holds true for DIC and TA: if DIC or TA were the controlling factor, SNW values should be more or less identical in the TA manipulation, given the little variation of DIC and TA in this manipulation (2215 \pm 23 and
$2490 \pm 202 \mu \mathrm{mol} \mathrm{kg-sw}^{-1}$, respectively) when compared to the large range in the $\mathrm{pH}$-stable manipulation (246-5729

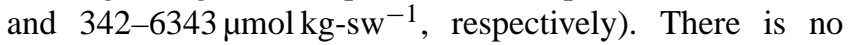
reason why SNW values should exhibit a large range (1.89-2.41 $\left.\mathrm{gg} \mathrm{\mu m}^{-1}\right)$ in this treatment, which is similar to the range exhibited in the $\mathrm{pH}$-stable manipulation, where the absolute change in DIC and TA is bigger by one order of magnitude. Consequently DIC and TA cannot be the parameters affecting SNW. Hence, based on the exclusion of certain correlations, $\left[\mathrm{CO}_{3}^{2-}\right]$ and $\Omega_{\mathrm{c}}$ are the only two candidates that could be responsible for the observed change in SNW. However, foraminifera do not respond to $\Omega_{\mathrm{c}}$ as such, but to the concentrations of $\mathrm{Ca}^{2+}$ and $\mathrm{CO}_{3}^{2-}$. Since calcium concentration in the culturing seawater was constant in all treatments (Table 1), we can conclude that carbonate ion concentration is the parameter of the carbonate system affecting SNW (homogeneous regression slopes at $p<0.05)$ with the following correlation: SNW $\left(10^{-2} \mu \mathrm{g} \mathrm{m}^{-1}\right)=1.76( \pm 0.06)+9.51 \times 10^{-4}\left( \pm 1.0 \times 10^{-4}\right)$ $\times\left[\mathrm{CO}_{3}^{2-}\right]$.

\subsubsection{Growth rate}

Please note that the reasoning of the extensive discussion of SNW applies also to growth rate. We therefore refrain from repeating the chain of arguments and just mention that growth rate and SNW are positively correlated. It is concluded that carbonate ion concentration is the parameter influencing growth rate in Ammonia sp. This conclusion tallies with response patterns of other species studied (Manno et al., 2012; Lombard et al., 2010; Russell et al., 2004; Kuroyanagi et al., 2009; Bijma et al., 2002). However, all of the latter studies, with the exception of the one by Bijma et al. (2002), employed either DIC-manipulation or TA-manipulation methods and could therefore not identify a single parameter responsible for observed adverse effects. 


\subsection{Implications for foraminiferal calcification}

The conclusion that carbonate ion concentration influences growth rate in Ammonia sp. poses the question why this is so. On the basis of our data, we cannot answer that question with any confidence, but one possibility could be the direct usage of carbonate ions for calcification by Ammonia sp. (Ter Kuile et al., 1989) have observed highest DIC uptake between $\mathrm{pH} 8$ and 9 and concluded that bicarbonate might be the inorganic carbon species that is preferentially taken up by Amphistegina lobifera, since this is the prevailing DIC species at that $\mathrm{pH}$ range (e.g. Zeebe and Wolf-Gladrow, 2001). However, they could not exclude the possibility of $\mathrm{CO}_{2}$ or $\mathrm{CO}_{3}^{2-}$ as DIC sources. Recent results suggest that foraminifera are capable of manipulating the inorganic carbon speciation by elevating the intracellular pH during calcification (de Nooijer et al., 2009). Model calculations of Wolf-Gladrow et al. (1999) show that the rate of chamber formation determines what DIC species might be used in the calcification process: while comparably fast (e.g., Globigerinoides sacculifer: $15.6 \mathrm{nmol} \mathrm{CaCO}_{3} \mathrm{~h}^{-1}$, Wolf-Gladrow et al., 1999) rates can only be explained if both carbonate and bicarbonate ions are used or an internal DIC pool is assumed, slower growth rates (e.g., Orbulina universa, $<5 \mathrm{nmol} \mathrm{CaCO}_{3} \mathrm{~h}^{-1}$, Wolf-Gladrow et al., 1999) can be sustained when only carbonate ions are used in the calcification process. The calculated relatively slow chamber formation rate of ca. $0.28 \mathrm{nmol} \mathrm{CaCO}_{3} \mathrm{~h}^{-1}$ (Glas et al., 2012) for Ammonia sp. would theoretically allow the sole utilization of carbonate ions. This is in accordance with our conclusion based on the correlation between SNW, growth rates and carbonate ion concentration. Up to now it remains unclear whether reduced calcification will affect the survival of foraminifera in the future, but evidence has been provided from naturally $\mathrm{CO}_{2}$-rich environments (Fabricius et al., 2011; Dias et al., 2010) that a reduction in foraminiferal diversity and abundance is associated with high $p \mathrm{CO}_{2} / \mathrm{low}$ $\left[\mathrm{CO}_{3}^{2-}\right]$ levels. This could potentially affect marine ecosystems and oceanic uptake of atmospheric $\mathrm{CO}_{2}$, since a reduction in planktonic foraminiferal ballast would reduce organic carbon export to deeper waters (Passow, 2004).

\subsection{Size-normalized weight as a carbonate ion proxy}

Foraminiferal SNWs have been proposed to serve as a proxy for seawater carbonate ion concentration and thereby for atmospheric $\mathrm{CO}_{2}$ concentrations (e.g., Barker and Elderfield, 2002; Moy et al., 2009; Gonzalez-Mora et al., 2008; Naik et al., 2010; de Moel et al., 2009). The sensitivity of the relationship between foraminiferal SNW and $\left[\mathrm{CO}_{3}^{2-}\right]$ from field studies is different between species. The SNW of Globigerinoides bulloides decreases by approximately $35 \%$ with a decrease in $\left[\mathrm{CO}_{3}^{2-}\right]$ of 250 to $200 \mu \mathrm{mol} \mathrm{kg}{ }^{-1}$, while over the same interval SNWs of Neogloboquadrina pachyderma do change considerably (Barker and Elderfield, 2002). The re- lationship between the SNW for Ammonia sp. and $\left[\mathrm{CO}_{3}^{2-}\right]$ found here results in a smaller change in SNW (approximately $40 \%$ over a decrease from 500 to $100 \mu \mathrm{mg}^{-1}$ $\left[\mathrm{CO}_{3}^{2-}\right]$; Fig. 2). These differences may partly be caused by differences in determination of the SNW, which is known to influence inferred SNW-environmental parameter relationships (Beer et al., 2010). Another reason for differences in the sensitivity of the SNW- $\left[\mathrm{CO}_{3}^{2-}\right]$ relationship may be caused by differences in morphology between species and thus underscores the need for species-specific calibrations when applying SNW as a proxy for seawater $\left[\mathrm{CO}_{3}^{2-}\right]$. Thirdly, the effect of $\left[\mathrm{CO}_{3}^{2-}\right]$ on SNW may also be modified by the presence (in Globigerinoides ruber) or absence (in G. bulloides, N. pachyderma and Ammonia sp.) of photosynthetic symbionts that indirectly affect calcification in foraminifera. Assuming that the dependency of SNW on $\left[\mathrm{CO}_{3}^{2-}\right]$ (rather than another component of the carbonate system) reported here is equally true for other (planktic) species, foraminiferal SNW in combination with another carbonate system proxy (e.g., boron isotopes as paleo-pH-proxy, e.g., Hemming and Hanson, 1992) could provide a paleoceanographic tool to aid in reconstructing the complete marine carbonate system.

\section{Conclusions}

We cultured the benthic foraminifera Ammonia sp. under two carbonate chemistry manipulations. The experimental setup allowed us to conclude that the observed increase in SNW and growth rate was caused by increasing $\left[\mathrm{CO}_{3}^{2-}\right]$, despite the overall high variability in SNW and growth rates, which are a common feature for cultured Ammonia sp. These observations on Ammonia sp. confirm the strong potential of SNW as a $\left[\mathrm{CO}_{3}^{2-}\right]$ proxy.

Acknowledgements. We in particular wish to thank Klaus-Uwe Richter for support with the experimental setup. Caroline Otten, Yvette Bublitz, Marc Bullwinkel, Jana Hölscher, Beate Müller, and Charlyn Völker are thanked for laboratory assistance. This work was supported by the European Commission through grant 211384 (EU FP7 "EPOCA"). Financial support for BIOACID was provided by the German Federal Ministry of Education and Research (BMBF, FKZ 03F0608). The research leading to these results has received funding from the European Community's Seventh Framework Programme under grant agreement 265103 (Project MedSeA). This work was funded in part by The European Research Council (ERC grant 2010-NEWLOG ADG-267931 HE). Nina Keul is the beneficiary of a doctoral grant from the AXA Research Fund.

Edited by: H. Kitazato 


\section{References}

Allison, N., Austin, W., Paterson, D., and Austin, H.: Culture studies of the benthic foraminifera Elphidium williamsoni: Evaluating $\mathrm{pH}, \Delta\left[\mathrm{CO}_{3}^{2-}\right]$ and inter-individual effects on test $\mathrm{Mg} / \mathrm{Ca}$, Chem. Geol., 274, 87-93, doi:10.1016/j.chemgeo.2010.03.019, 2010.

Anderson, O. R. and Faber, W. W.: An estimation of calcium carbonate deposition rate in a planktonic foraminifer Globigerinoides sacculifer using $45 \mathrm{Ca}$ as a tracer; a recommended procedure for improved accuracy, J. Foramin. Res., 14, 303-308, 1984.

Barker, S. and Elderfield, H.: Foraminiferal Calcification Response to Glacial-Interglacial Changes in Atmospheric $\mathrm{CO}_{2}$, Science, 297, 833-836, doi:10.1126/science.1072815, 2002.

Beer, C. J., Schiebel, R., and Wilson, P. A.: Testing planktic foraminiferal shell weight as a surface water $\left[\mathrm{CO}_{3}^{2-}\right]$ proxy using plankton net samples, Geology, 38, 103-106, 2010.

Bijma, J., Spero, H. J., and Lea, D. W.: Reassessing Foraminiferal Stable Isotope Geochemistry: Impact of the Oceanic Carbonate System (Experiemental Results), in: Use of Proxies in Paleoceanography: Examples from the South Atlantic, edited by: Fischer, G. and Wefer, G., 489-512, Springer-Verlag, Heidelberg, 1999.

Bijma, J., Hönisch, B., and Zeebe, R. E.: Impact of the ocean carbonate chemistry on living foraminiferal shell weight: Comment on Carbonate ion concentration in glacial-age deep waters of the Caribbean Sea by W. S. Broecker and E. Clark, Geochem. Geophys. Geosyst., 3, 1064, doi:10.1029/2002GC000388, 2002.

Caldeira, K. and Wickett, M. E.: Ocean model predictions of chemistry changes from carbon dioxide emissions to the atmosphere and ocean, J. Geophys. Res., 110, C09S04, doi:10.1029/2004JC002671, 2005.

Cigliano, M., Gambi, M., Rodolfo-Metalpa, R., Patti, F., and HallSpencer, J.: Effects of ocean acidification on invertebrate settlement at volcanic $\mathrm{CO}_{2}$ vents, Mar. Biol., 157, 2489-2502, doi:10.1007/s00227-010-1513-6, 2010.

Cuif, J., Dauphin, Y., and Sorauf, J.: Biominerals and fossils through time, Cambridge University Press Cambridge, UK, 2011.

de Moel, H., Ganssen, G. M., Peeters, F. J. C., Jung, S. J. A., Kroon, D., Brummer, G. J. A., and Zeebe, R. E.: Planktic foraminiferal shell thinning in the Arabian Sea due to anthropogenic ocean acidification?, Biogeosciences, 6, 1917-1925, doi:10.5194/bg-61917-2009, 2009.

de Nooijer, L. J., Reichart, G. J., Dueñas-Bohórquez, A., Wolthers, M., Ernst, S. R., Mason, P. R. D., and van der Zwaan, G. J.: Copper incorporation in foraminiferal calcite: results from culturing experiments, Biogeosciences, 4, 493-504, doi:10.5194/bg4-493-2007, 2007.

de Nooijer, L. J., Toyofuku, T., and Kitazato, H.: Foraminifera promote calcification by elevating their intracellular $\mathrm{pH}$, P. Natl. Acad. Sci., 106, 15374-15378, 2009.

Dias, B. B., Hart, M. B., Smart, C. W., and Hall-Spencer, J. M.: Modern seawater acidification: the response of foraminifera to high- $\mathrm{CO}_{2}$ conditions in the Mediterranean Sea, J. Geol. Soc., 167, 843-846, 2010.
Dickson, A. G. and Millero, F. J.: A comparison of the equilibrium constants for the dissociation of carbonic acid in seawater media, Deep-Sea Res., 34, 1733-1743, 1987.

Dickson, A., Sabine, C., Christian, J., et al.: Guide to best practices for ocean $\mathrm{CO}_{2}$ measurements, PICES Special Publication, 3, 2007.

Dissard, D., Nehrke, G., Reichart, G. J., and Bijma, J.: Impact of seawater $p \mathrm{CO}_{2}$ on calcification and $\mathrm{Mg} / \mathrm{Ca}$ and $\mathrm{Sr} / \mathrm{Ca}$ ratios in benthic foraminifera calcite: results from culturing experiments with Ammonia tepida, Biogeosciences, 7, 81-93, doi:10.5194/bg-7-81-2010, 2010.

Doney, S. C., Fabry, V. J., Feely, R. A., and Kleypas, J. A.: Ocean Acidification: The Other $\mathrm{CO}_{2}$ Problem, Annu. Rev. Mar. Sci., 1, 169-192, 2009.

Dueñas-Bohórquez, A., Raitzsch, M., de Nooijer, L. J., and Reichart, G.-J.: Independent impacts of calcium and carbonate ion concentration on $\mathrm{Mg}$ and $\mathrm{Sr}$ incorporation in cultured benthic foraminifera, Mar. Micropaleontol., 81, 122-130, 2011.

Fabricius, K., Langdon, C., Uthicke, S., Humphrey, C., Noonan, S., De'ath, G., Okazaki, R., Muehllehner, N., Glas, M., and Lough, $\mathrm{J}$.: Losers and winners in coral reefs acclimatized to elevated carbon dioxide concentrations, Nat. Clim. Change, 1, 165-169, 2011.

Fabry, V. J., Seibel, B. A., Feely, R. A., and Orr, J. C.: Impacts of ocean acidification on marine fauna and ecosystem processes, ICES J. Mar. Sci., 65, 414-432, 2008.

Fujita, K., Hikami, M., Suzuki, A., Kuroyanagi, A., Sakai, K., Kawahata, H., and Nojiri, Y.: Effects of ocean acidification on calcification of symbiont-bearing reef foraminifers, Biogeosciences, 8, 2089-2098, doi:10.5194/bg-8-2089-2011, 2011.

Glas, M. S., Langer, G., and Keul, N.: Calcification acidifies the microenvironment of a benthic foraminifer (Ammonia sp.), J. Exp. Mar. Biol. Ecol., 424-425, 53-58, 2012.

Gonzalez-Mora, B., Sierro, F. J., and Flores, J. A.: Controls of shell calcification in planktonic foraminifers, Quat. Sci. Rev., 27, 956961, 2008.

Haynert, K., Schönfeld, J., Riebesell, U., and Polovodova, I.: Biometry and dissolution features of the benthic foraminifer Ammonia aomoriensis at high $p \mathrm{CO}_{2}$, Mar. Ecol.-Prog. Ser., 432, 53-67, doi:10.3354/meps09138, 2011.

Haynert, K., Schönfeld, J., Polovodova-Asteman, I., and Thomsen, $\mathrm{J}$.: The benthic foraminiferal community in a naturally $\mathrm{CO}_{2}$-rich coastal habitat of the southwestern Baltic Sea, Biogeosciences, 9, 4421-4440, 2012, doi:10.5194/bg-9-4421-2012, 2012.

Hayward, B. W., Holzmann, M., Grenfell, H. R., Pawlowski, J., and Triggs, C. M.: Morphological distinction of molecular types in Ammonia - towards a taxonomic revision of the world's most commonly misidentified foraminifera, Mar. Micropaleontol., 50, 237-271, 2004.

Hemleben, C., Spindler, M., Breitinger, I., and Ott, R.: Morphological and physiological responses of Globigerinoides sacculifer (Brady) under varying laboratory conditions, Mar. Micropaleontol., 12, 305-324, 1987.

Hemming, N. G. and Hanson, G. N.: Boron isotopic composition and concentration in modern marine carbonates, Geochim. Cosmochim. Ac., 56, 537-543, 1992.

Hikami, M., Ushie, H., Irie, T., Fujita, K., Kuroyanagi, A., Sakai, K., Nojiri, Y., Suzuki, A., and Kawahata, H.: Contrasting calcification responses to ocean acidification between two reef 
foraminifers harboring different algal symbionts, Geophys. Res. Lett., 38, L19601, doi:10.1029/2011GL048501, 2011.

Hoppe, C., Langer, G., and Rost, B.: Emiliania huxleyi shows identical responses to elevated $p \mathrm{CO}_{2}$ in TA and DIC manipulations, J. Exp. Mar. Biol. Ecol., 406, 54-62, 2011.

Hoppe, C. J. M., Langer, G., Rokitta, S. D., Wolf-Gladrow, D. A., and Rost, B.: Implications of observed inconsistencies in carbonate chemistry measurements for ocean acidification studies, Biogeosciences, 9, 2401-2405, 2012,

http://www.biogeosciences.net/9/2401/2012/.

Keul, N., Langer, G., de Nooijer, L. J., Nehrke, G., Reichart, G.-J., and Bijma, J.: Incorporation of uranium in benthic foraminiferal calcite reflects seawater carbonate ion concentration, Geochemistry, Geophysics, Geosystems, 14, 102-111, doi:10.1029/2012GC004330, 2013.

Kuroyanagi, A., Kawahata, H., Suzuki, A., Fujita, K., and Irie, T.: Impacts of ocean acidification on large benthic foraminifers: Results from laboratory experiments, Mar. Micropaleontol., 73, 190-195, 2009.

Langdon, C. and Atkinson, M. J.: Effect of elevated $p \mathrm{CO}_{2}$ on photosynthesis and calcification of corals and interactions with seasonal change in temperature/irradiance and nutrient enrichment, J. Geophys. Res., 110, C09S07, doi:10.1029/2004JC002576, 2005.

Langer, G. and Bode, M.: $\mathrm{CO}_{2}$ mediation of adverse effects of seawater acidification in Calcidiscus leptoporus, Geochem. Geophys. Geosyst., 12, Q05001, doi:10.1029/2010GC003393, 2011.

Langer, G., Geisen, M., Baumann, K.-H., Kläs, J., Riebesell, U., Thoms, S., and Young, J. R.: Species-specific responses of calcifying algae to changing seawater carbonate chemistry, Geochem. Geophys. Geosyst., 7, Q09006, doi:10.1029/2005GC001227, 2006.

Langer, G., Nehrke, G., Probert, I., Ly, J., and Ziveri, P.: Strain-specific responses of Emiliania huxleyi to changing seawater carbonate chemistry, Biogeosciences, 6, 2637-2646, doi:10.5194/bg-6-2637-2009, 2009.

Lombard, F., da Rocha, R. E., Bijma, J., and Gattuso, J.-P.: Effect of carbonate ion concentration and irradiance on calcification in planktonic foraminifera, Biogeosciences, 7, 247-255, doi:10.5194/bg-7-247-2010, 2010.

Manno, C., Morata, N., and Bellerby, R.: Effect of ocean acidification and temperature increase on the planktonic foraminifer Neogloboquadrina pachyderma (sinistral), Polar Biol., 35, 1311-1319, 2012.

McIntyre-Wressnig, A., Bernhard, J., M., McCorkle, D., C., and Hallock, P.: Non-lethal effects of ocean acidification on the symbiont-bearing benthic foraminifer Amphistegina gibbosa, Mar. Ecol.-Prog. Ser., 472, 45-60, doi:10.3354/meps09918, 2013.

Mehrbach, C., Culberson, C. H., Hawley, J. E., and Pytkowicz, R. M.: Measurement of the Apparent Dissociation Constants of Carbonic Acid in Seawater at Atmospheric Pressure, Limnol. Oceanogr., 18, 897-907, 1973.

Moy, A. D., Howard, W. R., Bray, S. G., and Trull, T. W.: Reduced calcification in modern Southern Ocean planktonic foraminifera, Nature Geosci, 2, 276-280, doi:10.1038/ngeo460, 2009.

Naik, S. S., Naidu, P. D., Govil, P., and Godad, S.: Relationship between weights of planktonic foraminifer shell and surface water
$\mathrm{CO} 3=$ concentration during the Holocene and Last Glacial Period, Mar. Geol., 275, 278-282, 2010.

Passow, U.: Switching perspectives: Do mineral fluxes determine particulate organic carbon fluxes or vice versa, Geochem. Geophys. Geosyst, 5, Q04002, doi:10.1029/2003GC000670, 2004.

Petit, J. R., Jouzel, J., Raynaud, D., Barkov, N. I., Barnola, J. M., Basile, I., Bender, M., Chappellaz, J., Davis, M., Delaygue, G., Delmotte, M., Kotlyakov, V. M., Legrand, M., Lipenkov, V. Y., Lorius, C., Pepin, L., Ritz, C., Saltzman, E., and Stievenard, M.: Climate and atmospheric history of the past 420,000 years from the Vostok ice core, Antarctica, Nature, 399, 429-436, doi:10.1038/20859, 1999.

Pierrot, D., Lewis, E., and Wallace, D.: MS Excel program developed for $\mathrm{CO}_{2}$ system calculations, ORNL/CDIAC-105. Carbon Dioxide Information Analysis Center, Oak Ridge National Laboratory, US Department of Energy, Oak Ridge, Tennessee, 2006.

Raitzsch, M., Dueñas-Bohórquez, A., Reichart, G.-J., de Nooijer, L. J., and Bickert, T.: Incorporation of $\mathrm{Mg}$ and $\mathrm{Sr}$ in calcite of cultured benthic foraminifera: impact of calcium concentration and associated calcite saturation state, Biogeosciences, 7, 869881, doi:10.5194/bg-7-869-2010, 2010.

R Core Team: R: A Language and Environment for Statistical Computing, http://www.R-project.org/, iSBN 3-900051-07-0, 2012.

Reymond, C. E., Lloyd, A., Kline, D. I., Dove, S. G., and Pandolfi, J. M.: Decline in growth of foraminifer Marginopora rossi under eutrophication and ocean acidification scenarios, Glob. Change Biol., 19, 291-302, doi:10.1111/gcb.12035, 2013.

Rink, S., Koehl, M., Bijma, J., and Spero, H. J.: Microsensor studies of photosynthesis and respiration in the symbiotic foraminifer Orbulina universa, Mar. Biol., 131, 583-595, 1998.

Rost, B., Zondervan, I., and Wolf-Gladrow, D.: Sensitivity of phytoplankton to future changes in ocean carbonate chemistry: current knowledge, contradictions and research directions, Mar. Ecol.Prog. Ser., 227, 227-237, 2008.

Russell, A. D., Hönisch, B., Spero, H. J., and Lea, D. W.: Effects of seawater carbonate ion concentration and temperature on shell $\mathrm{U}$, $\mathrm{Mg}$, and $\mathrm{Sr}$ in cultured planktonic foraminifera, Geochim. Cosmochim. Ac., 68, 4347-4361, 2004.

Sabine, C. L., Feely, R. A., Gruber, N., Key, R. M., Lee, K., Bullister, J. L., Wanninkhof, R., Wong, C. S., Wallace, D. W. R., Tilbrook, B., Millero, F. J., Peng, T.-H., Kozyr, A., Ono, T., and Rios, A. F.: The Oceanic Sink for Anthropogenic $\mathrm{CO}_{2}$, Science, 305, 367-371, 2004.

Schiebel, R.: Planktic foraminiferal sedimentation and the marine calcite budget, Global Biogeochem. Cy., 16, 1065, doi:10.1029/2001GB001459, 2002.

Siegenthaler, U., Stocker, T. F., Monnin, E., Lüthi, D., Schwander, J., Stauffer, B., Raynaud, D., Barnola, J.-M., Fischer, H., Masson-Delmotte, V., and Jouzel, J.: Stable Carbon CycleClimate Relationship During the Late Pleistocene, Science, 310, 1313-1317, 2005.

Sinutok, S., Hill, R., Doblin, M. A., Wuhrer, R., and Ralph, P. J.: Warmer more acidic conditions cause decreased productivity and calcification in subtropical coral reef sediment-dwelling calcifiers, Limnol. Oceanogr., 56, 1200-1212, 2011.

Stoll, M. H. C., Bakker, K., Nobbe, G. H., and Haese, R. R.: Continuous-Flow Analysis of Dissolved Inorganic Carbon Content in Seawater, Anal. Chem., 73, 4111-4116, doi:10.1021/ac010303r, 2001. 
Ter Kuile, B., Erez, J., and Padan, E.: Competition for inorganic carbon between photosynthesis and calcification in the symbiontbearing foraminifer Amphistegina lobifera, Mar. Biol., 103, 253$259,1989$.

Uthicke, S. and Fabricius, K. E.: Productivity gains do not compensate for reduced calcification under near-future ocean acidification in the photosynthetic benthic foraminifer species Marginopora vertebralis, Glob. Change Biol., 18, 2781-2791, 2012.

Vogel, N. and Uthicke, S.: Calcification and photobiology in symbiont-bearing benthic foraminifera and responses to a high $\mathrm{CO}_{2}$ environment, J. Exp. Mar. Biol. Ecol., 424-425, 15-24, 2012.
Wolf-Gladrow, D. A., Bijma, J., and Zeebe, R. E.: Model simulation of the carbonate chemistry in the microenvironment of symbiont bearing foraminifera, Mar. Chem., 64, 181-198, 1999.

Zeebe, R. and Wolf-Gladrow, D.: $\mathrm{CO}_{2}$ in seawater: equilibrium, kinetics, vol. 65, Elsevier Science, 2001. 